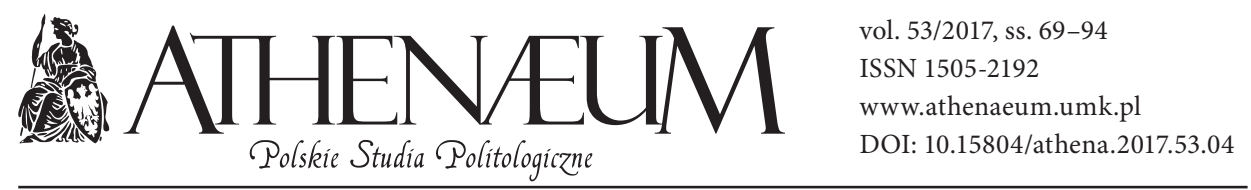

\title{
MIĘDZY ZAMKNIĘTOŚCIĄ A OTWARTOŚCIA. TRZY ZMIANY STATUSU I FUNKCJI KONTROLNYCH POLSKICH GRANIC
}

\author{
CLOSENESS VERSUS OPENNESS. \\ TREE MAJOR CHANGES OF THE POLITICAL STATUS \\ AND THE CONTROL FUNCTION OF THE POLISH BORDER
}

Monika Trojanowska-Strzęboszewska*$$
\text { - ABSTRAKT }
$$

W artykule ukazano przeobrażenia, jakie przeszły granice Polski od okresu powojennego, gdy w wyniku arbitralnych decyzji państw trzecich zostały zmienione przedwojenne usytuowanie i zasięg państwa polskiego, aż do dnia dzisiejszego, gdy status i funkcje granic III Rzeczpospolitej uległy gruntownej zmianie w wyniku członkostwa w UE i strefie Schengen. Szczególny nacisk położono na analizę trzech zasadniczych zmian statusu politycznego i funkcji kontrolnych tych granic. Pierwsza odnosi się do ustanowienia typowych dla ówczesnych krajów komunistycznych restrykcyjnych zasad ochrony i przekraczania granic tak przez obywateli polskich, jak i obywateli państw trzecich. Druga związana jest z radykalną zmianą zasad ochrony i kontroli polskich granic wraz $\mathrm{z}$ transformacją ustrojową i gospodarczą Polski na początku lat 90 . XX w., polegającą na względnym otwarciu wszystkich polskich granic na przepływ
\end{abstract}

The paper presents transformations that the Polish border have passed, from the period after World War II, when the pre-war location and extent of the Polish state have changed as a result of arbitrary decision of the leaders of the Soviet Union, Britain, and the United States, until today, when the status and the functions of the border of the Third Republic were changed as a result of Polish membership in the EU and the Schengen area. The emphasis is put on three modifications of the political status and the control function of borders. The first one is related to establishing very restrictive rules of border protection and border crossing (typical for communist countries) not only by third country nationals (TCNs) but also by Polish citizens. The second one is an effect of a radical change of rules of border protection and control as a part of systemic and economic transforma-

* Uniwersytet Kardynała Stefana Wyszyńskiego w Warszawie, Instytut Politologii. 
ludzi i towarów. Trzeci proces przeobrażeń polskich granic stanowi efekt integrowania się Polski z UE i jej przystąpienia do strefy Schengen. Polega na dywersyfikacji polskich granic na granice wewnętrzne i zewnętrzne UE, co istotnie zmienia nie tylko ich funkcje kontrolne, ale także status polityczny. Ukazanie powyższych zmian uzewnętrznia zmieniającą się naturę polityczną polskiego państwa i jego suwerenności. Analizy prowadzone są w ujęciu politologicznym, w oparciu o źródła instytucjonalno-prawne i literaturę przedmiotu.

Słowa kluczowe: granica państwowa, funkcje granic, kontrola granic, Unia Europejska, strefa Schengen tion in Poland in the early 1990s. Then the Polish border was open for liberal movement of people and goods. The third change of the Polish border is a result of the process of integration of Poland with the EU and the Schengen area. Generally speaking, the change meant the transformation of the Polish border in internal and external borders of the EU, what fundamentally transformed its control function and political status. All these changes of the Polish state border highlight the changeable nature of Polish state and its sovereignty.

Keywords: state border, functions of borders, border control, European Union, Schengen area

\section{WPROWADZENIE}

Dekadę po upadku „żelaznej kurtyny”, tryumfującym haśle „końca historii” i początku świata bez granic, w licznych pracach politologicznych ogłoszono powrót do terytorialności i wzrostu znaczenia granic państwowych w Europie ${ }^{1}$. Zauważono wówczas, że granice ponownie wracają na arenę międzynarodową, a nawet przeżywają swój prawdziwy renesans. Wzmacniają się ich rola i znaczenie w polityce krajowej i międzynarodowej, choć równocześnie funkcje pełnione przez granice podlegają licznym przeobrażeniom. Wydarzenia ostatnich dziesięciu lat pokazują, że procesy te nie słabną, a nawet się nasilają. W ostatnich latach zjawiska, takie jak: silna presja migracyjna do Unii Europejskiej, kryzys gospodarczy w wielu państwach członkowskich, a wraz z nim społeczne oczekiwanie ochrony krajowych rynków pracy, oraz wzrost skali i liczby aktów terrorystycznych, powodują, że granice państwowe umieszcza się w centrum zainteresowania politycznego i czyni kluczowymi instrumentami polityk bezpieczeństwa. Niemniej - jak podkreślają Hasting Donnan i Thomas M. Wilson (2007, s. 18) - współczesne granice międzypaństwowe „nie funkcjonują już w ten sam sposób jak kiedyś, a przynajmniej nie pod każdym względem. Globalizacja

1 Zob. m.in. Andreas, Snyder (2000); Andreas (2003); Murray, Holmes (1998); O’Dowd (2001); Anderson, Bort (2001). 
kultury, umiędzynarodowienie gospodarki i polityki, upadek groźnego mocarstwa i jego krajów satelickich z okresu zimnej wojny niewątpliwie zaowocowały otwarciem granic i osłabieniem kontroli państwowej, która ograniczała przepływ ludzi, dóbr, kapitału i idei”. W Europie na głębię i zakres transformacji granic międzypaństwowych silny wpływ wywarły przez wszystkim procesy integracyjne zachodzące w ramach Unii Europejskiej, w tym zwłaszcza powstanie strefy Schengen. Stąd też zarówno pogłębianie integracji w tym zakresie (m.in. poprzez stworzenie Kodeksu Granicznego Schengen, wspólnego kodeksu wizowego, stopniowe wdrażanie zintegrowanego systemu zarządzania granicami zewnętrznymi UE, a obecnie budowę wspólnej europejskiej straży granicznej i przybrzeżnej), jak i obecność tendencji przeciwnych, renacjonalistycznych (m.in. przywracanie kontroli na granicach wewnętrznych UE) gruntownie wpływają na status i funkcje pełnione przez granice międzypaństwowe w Europie. Zwłaszcza gdy spojrzy się na te procesy z szerszej i długofalowej perspektywy, uwidaczniają się zmiany, jakie zachodzą w naturze współczesnych granic oraz rolach, jakie one odgrywają w polityce, gospodarce i stosunkach społecznych.

W niniejszym artykule podjęta zostanie próba ukazania przeobrażeń, jakie przeszły granice Polski od okresu powojennego, gdy w wyniku arbitralnych decyzji przywódców ZSRR, Wielkiej Brytanii i USA zostały zmienione przedwojenne usytuowanie i zasięg państwa polskiego, aż do dnia dzisiejszego, gdy status i funkcje granic III Rzeczpospolitej uległy gruntownej zmianie w wyniku członkostwa Polski w UE i strefie Schengen. W artykule w syntetycznym ujęciu przedstawione zostaną trzy kluczowe transformacje tych granic. Należy przy tym zaznaczyć, że $\mathrm{z}$ uwagi na niezwykle szeroki zakres zagadnień związanych z przeobrażeniami granic międzypaństwowych w okresie od II wojny światowej do chwili obecnej, uwaga badawcza zostanie skoncentrowana jedynie na wybranych elementach tych procesów. Analizy obejmą w szczególności zmiany statusu politycznego i zasad funkcjonowania oraz realizacji funkcji kontrolnej na polskich granicach. Pozwoli to skoncentrować się na kluczowym w politologii rozumieniu granic w kategoriach dynamicznych instytucji politycznych, stanowiących integralny element wspólnoty politycznej, której zasięg wyznaczają, i odzwierciedlających zmiany, jakie dotykają jej instytucje i politykę.

U podstaw poniższych teoretycznych rozważań stoi bowiem definiowanie granic zarówno w kategoriach instytucji, jak i procesów. Za Malcolmem Andersonem $(1996$, s. 1) należy zaznaczyć, że granice są równocześnie dynamicznym przedmiotem polityki państwowej oraz instrumentem tej polityki. Jako instytucje granice wyznaczają i ograniczają suwerenność danego państwa oraz prawa 
poszczególnych obywateli. Ustanawiane są przez decyzje polityczne i regulowane przez akty prawne. A żadne zasady organizujące życie gospodarcze, społeczne i polityczne społeczeństw nie mogą działać bez granic. W ujęciu procesualnym granice stają się instrumentami polityki państwa, którego rządy mogą podejmować próby zmian, zgodnie $\mathrm{z}$ własnymi oczekiwaniami, ich lokalizacji i funkcji. $\mathrm{Z}$ drugiej strony w ujęciu tym uwypukla się fakt, że polityka i działania rządu są wyraźnie ograniczane przez poziom rzeczywistej kontroli sprawowanej przez daną władzę na granicach państwowych w określonym czasie (tamże, s. 2). Związki te podkreślają dynamiczny charakter i zmienną naturę granic. Ponadto granice jako miejsca, w których koncentruje się zróżnicowana działalność państwa, mogą stać się swoistym wyznacznikiem charakteru danej państwowości, a także stosunków państwa $z$ jego otoczeniem zewnętrznym. W tym sensie status polityczny (i prawny) konkretnych granic może ulegać modyfikacjom, a ich funkcje (role, zadania) mogą podlegać zmianom. Ta sama granica może być w pewnym czasie i okolicznościach politycznych (lub geopolitycznych) barierą, zaporą, kordonem ochronnym, miejscem separacji, by w innym czasie stać się mostem, miejscem wymiany, kontaktu i współpracy.

Należy zaznaczyć, że poniższe analizy zmian funkcji kontrolnej polskich granic zostaną przeprowadzone przez pryzmat ich otwartości (openness) versus zamkniętości (closeness). Kategorie te „odnoszą się do stopnia, w jakim granice tworzą lub znoszą bariery w przepływie ludzi i towarów" (Langer, 1999, s. 5). Otwartość-zamkniętość wyznaczane są przez warunki i możliwości legalnego przekraczania granicy w przejściach granicznych. Na otwartość-zamkniętość granicy wpływają wymagane do jej przekroczenia dokumenty tożsamości i zezwolenia (np. paszport, dowód tożsamości, wiza, zezwolenie na pobyt stały lub tymczasowy), dokumenty dodatkowe (np. ubezpieczenie zdrowotne czy zaproszenie), a także procedury i praktyki kontrolne prowadzone na granicy przez służby graniczne. Wszystkie te czynniki realnie wpływają na możliwości przekraczania granicy i uwarunkowane są obowiązującymi przepisami administracyjnymi poszczególnych państw, regulacjami prawnymi odnoszącymi się do konkretnych granic i przejść granicznych, a także bilateralnymi i multilateralnymi umowami międzynarodowymi zwieranymi przez poszczególne państwa. Pewnym uzupełnieniem analiz otwartości granic jest wskazanie na jej przenikalność rozumianą jako praktyczne możliwości nielegalnego przekraczania granic przez czynniki niepożądane na i między przejściami granicznymi. Na stopień przenikalności granicy wpływają cała jej infrastruktura techniczna, środki fizyczne i nowoczesne technologie służące jej kontroli i ochronie w zapobieganiu 
i wykrywaniu nielegalnego przekraczania granicy. Analizy z wykorzystaniem tych kategorii badawczych pozwolą pokazać rzeczywisty obraz zmieniających się zasad funkcjonowania polskich granic.

Artykuł podzielony został na trzy części, w których kolejno scharakteryzowane zostały, zgodnie z przyjętym założeniem badawczych, trzy kluczowe transformacje polskich granic państwowych. Pierwsza $\mathrm{z}$ transformacji związana jest z tworzeniem nowego powojennego porządku w Europie, obejmującego zmiany wielu granic międzypaństwowych oraz podział Europy (i świata) na dwa wrogie ideowo, polityczne i gospodarczo bloki państw, rozdzielone od siebie tzw. żelazną kurtyną. Druga wynika z procesów transformacji politycznej oraz gospodarczej w Europie Środkowej i Wschodniej na przełomie lat 80. i 90. XX w., związanych z upadkiem bloku państw komunistycznych na czele z ZSRR. Trzeci proces przeobrażeń polskich granic stanowi efekt integrowania się Polski z Unią Europejską i jej przystąpienia do strefy Schengen. Ukazanie tych trzech transformacji statusu politycznego i funkcji kontrolnych polskich granic państwowych pozwoli ukazać zmieniającą się naturę polityczną polskiego państwa i jego suwerenności.

\section{PRZEBIEG I SPECYFIKA POLSKICH GRANIC PO II WOJNIE ŚWIATOWEJ/DO 1989 R.}

Przebieg obecnych polskich granic został ustalony jeszcze w latach II wojny światowej w trakcie konferencji pokojowych Wielkiej Trójki (trzech mocarstw koalicji antyhitlerowskiej: Wielkiej Brytanii, USA i ZSRR). Kluczowe rozstrzygnięcia dotyczące usytuowania polskich granic na wschodzie, a po części także na zachodzie zapadły już w Teheranie w 1943 r. (Roszkowski, 2007, s. 125). Bez udziału przedstawicieli polskiego rządu emigracyjnego zdecydowano wówczas o usytuowaniu nowego polskiego państwa między linią rzeki Odry na zachodzie i tzw. linią Curzona² (tj. linia rzeki Bug z włączeniem Białostocczyzny, Suwalszczyzny oraz Rzeszowszczyzny do Polski) na wschodzie. Te ogólne ustalenia zostały doprecyzowane oraz uzupełnione o ustalenie przebiegu polskich granic także na północy i południu na kolejnych konferencjach w Jałcie i Poczdamie.

2 Linia Curzona, której nazwa pochodzi od nazwiska ministra spraw zagranicznych Wielkiej Brytanii, była linią przebiegu polskiej granicy na wschodzie, którą Brytyjczycy proponowali Rosji Radzickiej w 1920 r. Propozycja ta nie została zrealizowana. Przebieg granicy polskiej na wschodzie był efektem wygranej przez Polskę wojny z ZSRR i usankcjonowany traktatem ryskim z $1921 \mathrm{r}$. 
W efekcie tych arbitralnych i narzuconych Polsce decyzji ${ }^{3}$ pozostawiono poza polskim terytorium należące do II Rzeczypospolitej ziemie wschodnie: Polesie, Podole, Wołyń i Wileńszczyznę z dwoma ważnymi polskimi miastami: Lwowem i Wilnem. Z kolei tytułem rekompensat przyznano Polsce część południową Prus Wschodnich (bez Królewca) z byłym Wolnym Miastem Gdańskiem oraz tzw. Ziemie Zachodnie, należące do polskiego państwa w czasach średniowiecza, na których w 1945 r. większość ludności stanowili Niemcy. Ówczesne zmiany terytorialne pociągnęły za sobą masowe i przymusowe przesiedlenia przede wszystkim ludności polskiej z terenów dawnej II Rzeczpospolitej oraz ludności niemieckiej z terenów przyznanych po II wojnie światowej Polsce. W rezultacie tych bezprecedensowych w XX w. wędrówek ludów, trwających do początku lat 50. XX w., Polska stała się państwem niemal jednolitym narodowościowo, w którym mniejszości narodowe stanowiły około 2\% ludności (tamże, s. 158).

Zarówno sam sposób ustanowienia, jak i wyznaczony zasięg terytorium Polskiej Rzeczpospolitej Ludowej, nowego i pozbawionego pełnej niepodległości państwa polskiego, który politycznie, gospodarczo i ideowo powiązany został z ZSRR, istotnie wpłynęły na cechy ówczesnych polskich granic. Przebieg nowych granic Polski w znacznym stopniu oparto na czynnikach naturalnych. Granice te wyznaczono zgodnie z przebiegiem rzek: na zachodnie wzdłuż Odry, na wschodzie wzdłuż Bugu, na południu wzdłuż łańcuchów górskich, zaś na północy granicę w przeważającej mierze wyznaczało Morze Bałtyckie. Odwołując się do klasycznego podziału granic, były to więc granice fizyczne, wyznaczone przez przyrodę. Jedynie na północnym-wschodnie ich przebieg ma charakter geometryczny (linia prosta, sztucznie wytyczona na mapie) i tylko w nielicznych odcinkach są to granice złożone, rozumiane jako linie kompromisowe. Takie usytuowanie granic Polski oznaczało, że nie były to granice historyczne, ale całkowicie nowe, nieistniejące poprzednio, granice polityczne. Część z tych granic wytyczono w poprzek dawnych, historycznych i kulturowych regionów, zwłaszcza na Północny i Wschodzie, czego najbardziej ewidentnym przykładem była granica przecinająca dawne Prusy Wschodnie. Praktycznie żadna z nowych

3 Należy zaznaczyć, że przedstawiciele polskiego rządu emigracyjnego z premierem Mikołajczykiem na czele nie uzyskali nawet możliwości przedstawienia swojego stanowiska na temat przebiegu granic przyszłego państwa polskiego podczas konferencji Wielkiej Trójki. Z kolei już w lipcu 1944 r. rząd ZSRR doprowadził do podpisania umowy granicznej sankcjonującej przebieg polskiej granicy wschodniej zgodnie z linią Curzona z komunistycznym Polskim Komitetem Wyzwolenia Narodowego, samozwańczym ośrodkiem władzy wykonawczej jako alternatywą dla rządu RP na uchodźstwie (Eberhardt, 1993). 
granic Polski nie miała charakteru granicy antropogeograficznej, tj. stanowiącej granice historycznego regionu zachowujących swoistą odrębność kulturową, językową, etniczną i religijną, ale też pewną spójność ekonomiczną i infrastrukturalną. Sytuacja ta oznaczała, że pierwotnie powojenne granice Polski nie były wyraziste ani kulturowo, ani ekonomicznie. Ową wyrazistość kulturowo-etniczną budowano szczególną polityką państwa wobec pograniczy i ludności je zamieszkującej (głównie poprzez osiedlanie na pograniczach wschodnich i północnych ludności z centralnej Polski, zaś na ziemiach zachodnich polskich przesiedleńców z terenów zajętych przez ZSRR), ukierunkowaną na to, aby struktura etniczna pograniczy odpowiadała wizji homogenicznego narodowo i etnicznie państwa polskiego.Z kolei wytyczenie granic z pominięciem spójności infrastrukturalnej i gospodarczej regionów wiązało się z marginalizacją i zubożeniem polskich terenów przygranicznych zarówno na wschodzie, jak i zachodzie kraju, pozbawionych wielu szlaków komunikacyjnych i odciętych od dotychczasowych ośrodków rozwoju. Sytuacja ta doprowadziła do upadku wielu miast, zwłaszcza mniejszych, a w efekcie oznaczała nadanie terenom przygranicznym charakteru peryferyjnego.

Mając na uwadze fakt, że jednym z kluczowych determinantów charakteru i funkcji pełnionych przez granice są stosunki z państwami sąsiednimi, należy wskazać na ówczesną przynależność Polski do grupy krajów komunistycznych pod protektoratem ZSRR. Oznaczało to, że teoretycznie Polska sąsiadowała wyłącznie z państwami, z którymi utrzymywała przyjacielskie stosunki i żadne z tych państw nie zgłaszało roszczeń terytorialnych pod adresem Polski, a dodatkową gwarancję nienaruszalności tych granic stanowiła potęga ZSRR ${ }^{4}$. Na zachodzie Polska sąsiadowała z Niemiecką Republiką Demokratyczną, powstałą w miejsce radzieckiej strefy okupacyjnej w Niemczech po II wojnie światowej. Zaś na południu Polska graniczyła z Republiką Czechosłowacką (od 1960 r. przemianowaną na Czechosłowacką Republikę Socjalistyczną), rządzoną przez komunistyczne władze także podporządkowane Moskwie. Wreszcie granica wschodnia i północno-wschodnia była granicą z ZSRR. Polska w nowych granicach po 1945 r. miała więc tylko tych trzech sąsiadów (w stosunku do siedmiu

4 Wprawdzie ustalenie przebiegu granicy polsko-czechosłowackiej odbywało się w sytuacji konfliktu politycznego, a nawet groźby konfliktu militarnego, spowodowanego roszczeniami terytorialnymi obu stron do siebie nawzajem, to konflikt ten zażegnała autorytarna i bezdyskusyjna decyzja Stalina z czerwca 1945 r. Radziecki dyktator zdecydował wówczas, że granica ta uzyska przebieg sprzed 1937 r., co przekreśliło roszczenia Polski do Śląska Zaolziańskiego oraz Czechosłowacji do Ziemi Kłodzkiej i Raciborskiej (Dominiczak, 1997, s. 331-333). 
w okresie przedwojennym), co diametralnie zmieniło jej układy sąsiedzkie w stosunkach międzynarodowych.

Wydawać by się mogło, że sąsiedztwo innych państw bloku komunistycznego, połączonych ideowo, politycznie, wojskowo i gospodarczo, powinno wpłynąć na wysoki poziom bezpieczeństwa i otwartości granic PRL, wyrażający się w liberalnych zasadach przekraczania tych granic i niskim systemie ich fizycznych zabezpieczeń. Paradoksalnie jednak ówczesne granice Polski, w sensie fizycznym i w zakresie poziomu ich otwartości, nie odbiegały od granic, jakie budowały między sobą państwa wykazujące do siebie wrogość. „Na granicach państw «wspólnoty socjalistycznej» powstały po obu stronach silne wojskowe kordony, które nie tylko zredukowały do niezbędnego minimum ruch graniczny z państwami kapitalistycznymi, lecz także komunistycznymi” (Dominiczak, 1997, s. 334). Granice strzeżone były przez formację wojskową, tzw. Wojska Ochrony Pogranicza, a nasycenie pasu granicznego (o szerokości $30 \mathrm{~km}$ od granicy w głąb kraju) wojskiem było bardzo duże. Na zielonych odcinkach granicy wzniesiono zapory z drutu kolczastego, zainstalowano wieże obserwacyjne oraz stworzono zaorany i zabronowany pas ziemi jako element kontrolny, ułatwiający wykrywanie ewentualnych przypadków nieuprawnionego przekroczenia granicy. Dodatkowo na granicach zachodnich i południowych wznoszono wysokie płoty z siatki drucianej, a wszystkie przepusty, ujścia rzek, kanały, wąwozy itp. przecinające granice zagrodzono drutem kolczastym. Wprowadzono też szereg uciążliwych przepisów dla ludności zamieszkujących tereny nadgraniczne. Złagodzenie obostrzeń w ochronie granicy oraz przepisów dotyczących strefy nadgranicznej nastąpiło po $1956 \mathrm{r}$. wraz z przemianami politycznymi w ZSRR, a następnie całym bloku wschodnim.

W okresie PRL-u sposób funkcjonowania polskich granic i wysoki poziom ich szczelności stały w sprzeczności z oficjalnie głoszoną doktryną dobrosąsiedzkich stosunków w grupie państw komunistycznych. Legalny wjazd do kraju sąsiedniego wiązał się z szeregiem trudności (m.in. w pozyskaniu paszportu, konieczności posiadania wielu zaświadczeń i zaproszenia, zakupie waluty itp.), a nielegalne przekroczenie granicy przez ludność zamieszkującą tereny przygraniczne, nawet w celu odwiedzenia rodziny czy grobów swoich przodków, było surowo karane. Paradoksalnie najwyższy poziom zamkniętości utrzymywano na granicy ze ZSRR, przede wszystkim z uwagi na wysoce restrykcyjną politykę wjazdową tego kraju i pełną kontrolę osób wjeżdżających do ZSRR. Przez cały okres PRL-u granica z ZSRR była jedną z najpilniej strzeżonych linii granicznych w Europie (Sadowski, 2001). Niechęć władz radzieckich do „otwierania” 
granic i przemieszczania się ludności wynikała przede wszystkim z obawy przed przenikaniem na terytorium ZSRR poglądów, wartości i idei odmiennych od głoszonych oficjalnie, a tym samym uznawanych za wrogie i niebezpieczne dla trwałości systemu komunistycznego. I nawet po 1956 r., gdy stopniowo liberalizowano przepisy paszportowe i wizowe oraz wprowadzano umowy o małym ruchu granicznym, nie dotyczyło to granicy z ZSRR.

Z uwagi na krępujące wolność człowieka i swobodę przemieszczania się, restrykcyjne przepisy dotyczące wyjazdów z kraju ${ }^{5}$ ruch graniczny w PRL-u był zredukowany do minimum. Po okresie masowych powojennych wędrówek ludności, licznych wysiedleni i repatriacji, od końca lat 40. XX w., zaostrzano reżim kontrolny na granicach, wprowadzając drobiazgową kontrolę dokumentów oraz szczegółowe przeszukania towarów i pojazdów w tzw. granicznych punktach kontrolnych, a także tworząc liczne zabezpieczenia przed nieuprawnionymi przekroczeniami granicy na jej odcinkach zielonych. W ciągu 10 pierwszych lat (1946-1955) granicę przekroczyło niecałe $50 \mathrm{mln}$ ludzi (łącznie z repatriantami). Od lat 60. XX w. ruch graniczny stopniowo wzrasta wraz z zawieranymi z krajami sąsiednimi umowami o uproszczonym ruchu granicznym dla wycieczek, osób zamieszkujących tereny przygraniczne czy w zakresie kontaktów gospodarczych i kulturalnych.

Największa liberalizacja w zakresie ruchu granicznego i zasad przekraczania granic w okresie PRL-u miała miejsce w latach 1972-1980. Wówczas to wprowadzono ruch bezpaszportowy w całym bloku komunistycznym, utrzymując jednak wymóg posiadania zaproszeń w podróżach do ZSRR. Dodatkowo władze polskie złagodziły politykę paszportową z krajami zachodnimi, podpisały umowy o ruchu bezwizowym z wybranymi krajami (Szwecją, Austrią, Finlandią), uruchomiły nowe przejścia na granicy zachodniej i południowej, a nawet umożliwiły przekraczanie granicy z NRD na podstawie pieczątki w dowodzie osobistym. $\mathrm{Na}$ skutek tych działań nastąpił znaczący wzrost natężenia ruchu granicznego, także w zakresie przyjazdów obcokrajowców do Polski. Nadal jednak istniało wiele ograniczeń w przekraczaniu polskich granic, związanych zarówno z limitowaniem wymiany walut dla osób wyjeżdżających, restrykcjami w zakresie polityki celnej i uciążliwymi praktykami kontrolnymi na granicach, a nawet ograniczeniami transportowymi (niewystarczająca liczba połączeń, trudności z kupieniem

5 Należy przypomnieć, że wyjazd z kraju był uzależniony od możliwości uzyskania paszportu, a decydentami w tej sprawie byli funkcjonariusze Służby Bezpieczeństwa. Stąd m.in. liczne w całym okresie PRL-u ucieczki z kraju przez tzw. zieloną granicę, głównie drogą morską. 
biletów itd.). W związku z wprowadzeniem stanu wojennego w grudniu $1981 \mathrm{r}$. granice zostały zamknięte, a wszystkie wcześniejsze ułatwienia w ruchu granicznym zostały zawieszone. Dopiero po 1983 r. stopniowo znoszono pewne ograniczenia paszportowe, zachowując jednak część - w latach poprzednich zniesionych - wymogów, jak konieczność posiadania zaproszenia, czy też ograniczenia w wywozie dewiz. Paradoksalne było wówczas to, że dużo liberalniejsze zasady obowiązywały w ruchu z wybranymi państwami zachodnimi niż z krajami sąsiednimi, w podróżach, do których obowiązywał, np. wymóg posiadania zaproszenia tylko od członka najbliższej rodziny. Pomimo tych ograniczeń ruch graniczny przez całą dekadę lat 80 . XX w. stopniowo wzrastał.

Ograniczona suwerenność Polski w okresie PRL i zależność polskiej polityki wewnętrznej i zewnętrznej od dyktatu ZSRR wyraźnie rzutowały na status ówczesnych polskich granic, zasady dotyczące ich funkcjonowania i wypełniania funkcji kontrolnej. Mając na uwadze, że cały okres PRL-u nie był jednorodny, jeżeli chodzi o obowiązujące wówczas zasady przekraczania granic, to pomimo pewnych okresów większej liberalizacji w tym zakresie, granice te, analogicznie do pozostałych granic międzypaństwowych w bloku państw komunistycznych, charakteryzowały się wysokim stopniem szczelności i nieprzepuszczalności. Wyróżniało je tworzenie przez władze licznych ograniczeń prawnych w ruchu granicznym, piętrzenie trudności administracyjnych w zakresie polityki paszportowej, wizowej, dewizowej oraz ograniczeń infrastrukturalnych w ruchu międzynarodowym, zarówno z krajami oficjalnie sojuszniczymi, jak i z państwami zachodnimi. Ponadto kontrola graniczna i ochrona granic państw socjalistycznych, w tym granic Polski, choć nie sąsiadowała ona bezpośrednio z żadnym państwem zachodnioeuropejskim, były w pełni zmilitaryzowane i prowadzone przez specjalne formacje wojskowe. Działania te służyć miały utrzymaniu jak najwyższego stopnia nieprzepuszczalności tych granic dla wszystkiego, co ówczesne władze uznały za zagrażające nie tyle bezpieczeństwu kraju, co stabilności i trwałości jego ustroju politycznego i gospodarczego. Były to więc granice polityczne izolujące kraj od wpływów zewnętrznych, ograniczające ruch obywateli (a co za tym idzie także wymianę myśli i poglądów) oraz wszelką współpracę gospodarczą, kulturalną i społeczną nie tylko z krajami o innym ustroju, ale także z państwami sąsiednimi. 


\section{"OTWIERANIE" GRANIC PO 1989 R.}

Gruntowna zmiana statusu politycznego i zasad funkcjonowania polskich granic nastąpiły wraz z przemianami demokratycznymi przełomu lat 80. i 90. XX w. zachodzącymi w całej Europie Wschodniej i Środkowej. Wprawdzie w wyniku tych transformacji zmianie nie uległa lokalizacja polskich granic, co nastąpiło w innych krajach bloku wschodniego, jednak granice całkowicie zmieniły swój status, znaczenie geopolityczne oraz pełnione funkcje.

Przede wszystkim w wyniku rozpadu ZSRR i ogłoszenia niepodległości przez sąsiadujące z Polską republiki Białorusi, Litwy, Rosji i Ukrainy, a także rozpadu Czechosłowacji oraz przyłączenia NRD do RFN Polska zyskała sześciu całkowicie nowych sąsiadów. Do końca 1992 r. mapa polityczna Europy Środkowej i Wschodniej uległa bowiem gruntowanej przebudowie. Na zachodnie graniczyła teraz z Republiką Federalną Niemiec (granica o długości 489,37 km), na północnym-wschodzie z Federacją Rosyjską (granica z Obwodem Kaliningradzkim o długości 232,04 km), zaś jej wschodnimi sąsiadami zostały: Republika Litewska (z granicą o dł. 104,28 km), Republika Białorusi (z granicą o dł. 418,24 km) oraz Ukraina (z granicą o dł. 535,18 km). Na południu Polska zyskała granice z Republiką Słowacką (granica o dł. 541,06 km) i Republiką Czeską (granica o dł. 796,04 km). Ze wszystkimi nowymi sąsiadami Polska na nowo musiała ułożyć relacje międzynarodowe, określić zasady współpracy politycznej, gospodarczej i społeczno-kulturowej, w tym także ustalić kwestie dotyczące wspólnych granic. Zadanie to nie było łatwe $\mathrm{z}$ uwagi na odmienne interesy i polityki zagraniczne nowych państw sąsiednich Polski, a w efekcie skutkowało znaczącym zróżnicowaniem stosunków z jej sąsiadami.

W tym szczególnym okresie tworzenia się nowego geopolitycznego ładu w Europie priorytetem polskiej polityki zagranicznej pierwszego niekomunistycznego rządu polskiego, z premierem Tadeuszem Mazowieckim na czele, stały się dążenie do zbudowania w Europie systemu bezpieczeństwa zbiorowego, równoważenie stosunków z dwoma kluczowymi sąsiadami: rozpadającym się ZSRR i jednoczącymi się Niemcami, oraz współpraca regionalna z krajami Europy Środkowej i Wschodniej6. Polska, sąsiadując teraz z RFN, stała się tym samym państwem granicznym Wspólnot Europejskich, a następnie Unii Europejskiej,

6 Priorytet kreowania współpracy w regionie Europy Środkowej na różnych płaszczyznach został urzeczywistniony m.in. w zawiązaniu kilku formuł współpracy międzynarodowej, jak Grupa Wyszehradzka, Środkowo-Europejska Strefa Wolnego Handlu i Inicjatywa Środkowoeuropejska. 
co w znacznym stopniu wpłynęło na jej dalsze wybory priorytetów politycznych. W kolejnych latach zostały one skonkretyzowane jako dążenie do uczestniczenia w europejskich i euroatlantyckich procesach integracji (w ramach NATO i UE).

W kwestii granic pożądane było przede wszystkim zapewnienie ich nienaruszalności oraz zerwanie $\mathrm{z}$ dotychczasowym izolacjonizmem, całkowicie sprzecznym $z$ interesem społeczeństwa i wolnorynkowej gospodarki. Sytuacja była o tyle dla Polski korzystna, że już w pierwszych latach 90. XX w., nowe państwa sąsiednie potwierdziły formalnie nienaruszalność polskich granic, czemu dano wyraz w podpisanych umowach o relacjach dobrosąsiedzkich (Szymański, 2014, s. 9-12). Dla polskich granic z Czechami, Słowacją i Litwą, których przebieg potencjalnie mógł okazać się problematyczny z uwagi na obciążenia historyczne, poza gwarancją traktatową ${ }^{7}$ istotną gwarancją stabilizacji wspólnej linii granicznej okazały się wybory geopolityczne, jakich dokonano w tych państwach. Państwa te, tak jak Polska ukierunkowując swoje poczynania międzynarodowe na udział w strukturach NATO i UE, w pełni zaakceptowały fundamentalne zasady integralności terytorialnej i nienaruszalności granic wpisane w podstawy traktatowe procesu integracji europejskiej.

Jednak dla bezpieczeństwa polskich granic kluczowe były przede wszystkim relacje z dwoma największymi sąsiadami: RFN i Federacją Rosyjską. Bez wątpienia sukcesem było to, że już w 1990 r. doszło do podpisania traktatu z Republiką Federalną Niemiec, w którym potwierdzono przebieg wspólnej granicy na Odrze i Nysie. Traktat ten został uzupełniony podpisanym w Bonn 17 czerwca 1991 r. Traktatem o dobrym sąsiedztwie i przyjaznej wspótpracy ${ }^{8}$, w którym m.in. podkreślono znaczenie pokojowego ułożenia stosunków polsko-niemieckich dla jedności europejskiej oraz zainicjowano na szeroką skalę płaszczyznę współpracy kulturalnej między krajami. W kolejnych latach wyraźnie rosła dynamika współpracy polsko-niemieckiej, zwłaszcza w obszarze gospodarczym oraz na płaszczyźnie współpracy regionalnej, poprzez tworzenie zinstytucjonalizowanych regionów transgranicznych.

7 Por. Układ między Rzecząpospolitą Polską a Czeską i Słowacką Republiką Federacyjną o dobrym sąsiedztwie, solidarności i przyjacielskiej współpracy sporządzony w Krakowie dnia 6 października 1991 r. (Dz. U. 1992 nr 59 poz. 296); Traktat między Rzecząpospolitą Polską a Republiką Litewską o przyjaznych stosunkach i dobrosąsiedzkiej współpracy, sporządzony w Wilnie dnia 26 kwietnia 1994 r. (Dz. U. 1995, nr 15, poz. 71).

8 Traktat między Rzecząpospolitą Polską a Republiką Federalną Niemiec o dobrym sąsiedztwie i przyjaznej współpracy, podpisany w Bonn dnia 17 czerwca 1991 r. (Dz. U. 1992 nr 14, poz. 56). 
W 1992 r. Polska podpisała także traktat z Federacją Rosyjską, w którym obie strony uznały swoją wspólną granicę za nienaruszalną i potwierdziły, że nie mają i mieć nie będą w przyszłości żadnych roszczeń terytorialnych do siebie nawzajem . Niemniej rzeczywisty wymiar stosunków politycznych z Rosją nie ułożył się już tak pomyślnie jak relacje polsko-niemieckie, $\mathrm{z}$ uwagi na silnie ugruntowany i nieprzezwyciężony przez nowe władze rosyjskie tradycyjny imperializm tego kraju, od lat 90. silnie umacniany przez wzrost tendencji nacjonalistycznych. Tendencje te wyrażały się w przyjętej przez Federację Rosyjską doktrynie „bliskiej zagranicy”, która była w istocie wyrazem braku rosyjskiej zgody na akceptację przebiegu jej nowych granic. Doktryna ta polegała na przyznaniu sobie szczególnych praw w relacjach z krajami powstałymi na bazie dawnych republik radzieckich, które wybiły się na niepodległość i niezależność. Oznaczała ona de facto traktowanie tych państw jako obszaru zastrzeżonego dla rosyjskich poczynań na arenie międzynarodowej. W ten sposób Rosja podchodziła do trzech bezpośrednio sąsiadujących z Polską krajów: Białorusi, Litwy i Ukrainy, co od początku stanowiło potencjalne źródło zagrożeń dla bezpieczeństwa i stabilności polskich granic na wschodzie ${ }^{10}$.

O ile Litwie, podobnie jak pozostałym krajom bałtyckim, pomimo prób rozbijania ich spójności państwowej przez Rosję przy pomocy znaczącej liczbowo mniejszości rosyjskiej, udało się wyjść spod rosyjskiej kurateli, o tyle pozostałym krajom sąsiadującym z Polską: Białorusi i Ukrainie, się to nie udało. Białoruś już od 1995 r. weszła w zasięg ścisłej zależności politycznej i gospodarczej od Rosji, usankcjonowanej podpisaną wówczas Umową o przyjaźni, dobrosąsiedztwie i współpracy pomiędzy Republikg Białorusi i Federacja Rosyjską oraz powołaniem w 1997 r. Związku Białorusi i Rosji. Zależność tę umacniano i poszerzano

9 Traktat między Rzecząpospolitą Polską a Federacją Rosyjską o przyjaznej i dobrosąsiedzkiej współpracy, sporządzony w Moskwie dnia 22 maja 1992 r. (Dz. U. 193 nr 61 poz. 291).

10 Należy zauważyć, że w swojej polityce zagranicznej Federacja Rosyjska od początku w szczególny sposób traktowała też kraje zaliczane do tzw. imperium zewnętrznego ZSRR (jak określano strefę jej wpływów w ramach rosyjskiej imperialnej doktryny w wydaniu komunistycznym), w tym Polskę. Oznaczało to postrzeganie krajów Europy Środkowej jako swojej przyrodzonej strefy wpływów i wyrażało się w działaniach na rzecz hamowania procesów integracji tych państw ze strukturami Zachodu, tj. NATO i UE (Rościszewski, 1997). Obserwując obecne poczynania władz rosyjskich wobec Europy Środkowej i Wschodniej, już od ponad 10 lat stanowiącej część UE, wydaje się, że Rosja nie zrezygnowała z głównych założeń swojej doktryny geopolitycznej. Nadal bowiem nie ustaje w działaniach zmierzających do rozbijania kruchej jedności europejskiej i antagonizowania państw Europy Środkowej z państwami tzw. starej UE. 
w kolejnych latach. W odniesieniu do kwestii granicznych jej wyrazem była praktycznie pełna otwartość granicy rosyjsko-białoruskiej, na której nie wprowadzono kontroli ruchu granicznego (z wyjątkiem samochodów ciężarowych), i która w niektórych miejscach nie została nawet wyznaczona w terenie. Sytuacja ta w naturalny sposób rzutowała na konieczność wzmożenia działań kontrolnych na granicach Polski z obydwoma tymi krajami.

Odmiennie od Białorusi ułożyły się relacje Rosji z Ukrainą, rzutujące na bezpieczeństwo i nienaruszalność polskiej granicy z Ukrainą. Ukraina początkowo opierała się rosyjskiemu imperializmowi dzięki silnemu poczuciu własnej państwowości i nacjonalizmowi, tworząc własne niezależne i suwerenne państwo. Jednak rosyjska presja ekonomiczna (głównie w zakresie dostaw surowców energetycznych) stopniowo doprowadziła do dezorganizacji części ukraińskiej gospodarki i w konsekwencji umacniania politycznych wpływów ugrupowań prorosyjskich w tym kraju. A gdy w odpowiedzi na tę presję część elit politycznych i ukraińskiego społeczeństwa zwracała się w kierunku Zachodu, presja rosyjska rosła, aż po aneksję Krymu w 2014 r. i interwencję zbrojną na wschodniej Ukrainie. W obliczu takiej polityki rosyjskiej działania władz polskich wobec Ukrainy były od początku uzyskania przez nią niepodległości konsekwentnie ukierunkowane na wspieranie europejskich aspiracji tego kraju, zarówno poprzez włączenie jej w struktury bezpieczeństwa NATO, jak i stopniowe integrowanie z obszarem wspólnego europejskiego rynku.

Pomimo przedstawionej powyżej złożoności i zróżnicowania stosunków politycznych z nowymi krajami sąsiednimi na wszystkich polskich granicach po 1989 r. nastąpił radykalny zwrot w kierunku liberalizacji przepisów dotyczących przekraczania granic. Przede wszystkim nowe polskie władze, podobnie jak inne kraje regionu, zlikwidowały uciążliwe i restrykcyjne przepisy dotyczące uzyskania paszportu i nabywania obcych walut. Wprowadzono też ruch bezwizowy pomiędzy krajami Europy Środkowej oraz krajami bałtyckimi i Ukrainą. Od początku lat 90. stopniowo wiele krajów europejskich (m.in. Niemcy, Francja, Włochy, Belgia, Holandia, Luksemburg, Norwegia, Szwecja, Finlandia) znosiło też obowiązek wizowy dla polskich obywateli. Ważnym wyrazem ówczesnego otwierania granic były podpisane z Niemcami (w 1992 r.), Czechami (w 1995 r.) i Słowacją (w 1996 r.) umowy o małym ruchu granicznym, ułatwiające przekraczanie granic przez ludność zamieszkującą pogranicza. Z kolei na granicy wschodniej i północno-wschodniej w 1993 r. uruchomiono kilkanaście przejść granicznych o uproszczonym trybie przekraczania granicy dla obywateli zamieszkujących tereny przygranicze. 
Zmiany te przyniosły dynamiczny wzrost ruchu granicznego. Już w $1991 \mathrm{r}$. ruch osobowy zwiększył się o 40\% w porównaniu do roku poprzedniego. W 1994 r. odprawiono w przejściach granicznych ponad $217 \mathrm{mln}$ osób i ponad 65 mln środków transportu (Dominiczak, 1996, s. 383). Największą intensywnością ruchu granicznego odznaczała się granica zachodnia, a w drugiej kolejności granica południowa. W kolejnych latach wzrósł też ruch graniczny na granicy wschodniej. W 1997 r. osobowy ruch graniczny na całym odcinku granicy wschodniej (wraz z granicą z FR) wynosił 29 mln osób, co stanowi wzrost o 74,3\% w porównaniu do roku 1991 (Sytuacja na granicy, 1998).

Gwałtowny wzrost ruchu granicznego osobowego i towarowego obnażył całkowity brak przystosowania infrastruktury granicznej do nowej sytuacji. Konieczne okazały się olbrzymie zmiany w tej infrastrukturze i organizacji punktów kontrolnych. W efekcie zmodyfikowano wiele starych i otworzono wiele nowych przejść granicznych drogowych i kolejowych oraz unowocześniono i zinformatyzowano infrastrukturę graniczną. Dzięki temu na granicy polsko-czeskiej średnie odległości między przejściami granicznymi wyniosły zaledwie 7 km, zaś na granicy polsko-niemieckiej ok. 12 km (Sobczyński, 2008, s. 51). Łącznie „w 2004 r. funkcjonowało w Polsce 259 przejść granicznych, w tym z 92 przejścia z Czechami, 52 ze Słowacją i 38 z Niemcami" (Sobczyński, 2008, s. 49). Duże zmiany wprowadzono też na granicy wschodniej.W 1990 r. na całym odcinku tej granicy istniało tylko pięć przejść granicznych, $w$ tym dwa drogowe i trzy kolejowe. Dla przykładu na najdłuższym odcinku granicy wschodniej, tj. z Ukrainą, gdzie przed 1989 r. istniało tylko przejście w Medyce, otworzono przejścia w Dorohusku (w 1990 r.), Hrebennem (w 1991 r.), Krościenku i Zosinie (w 1994 r.) oraz w Korczowej w 1998 r. Równolegle zwiększano też liczbę przejść na granicy z Białorusią i Rosją, a także z Litwą, chociaż nadal odczuwalny był niedorozwój infrastruktury granicznej na granicy wschodniej.

W latach 90. nastąpił też proces całkowitej transformacji systemu patrolowania, kontrolowania i zarządzania polskimi granicami. W 1990 r. wprowadzono ustawę o ochronie granicy państwowej (Ustawa, 1990), która określiła nowe zasady jej ochrony, kontroli ruchu granicznego, wykrywania i ściągania przestępstw transgranicznych. Zliberalizowano zasady zamieszkiwania i przebywania w strefie nadgranicznej, ograniczając ją do szerokość do $15 \mathrm{~km}$ od linii granicznej. Zadania ochrony granicy i kontroli ruchu granicznego powierzono nowo zorganizowanej (na wzór formacji przedwojennej) Straży Granicznej, zmieniając dotychczasowy charakter formacji granicznej z wojskowego na cywilno-wojskowy. Wprowadzono szereg nowych przepisów kontroli ruchu granicznego 
oraz zwalczania i wykrywania przestępczości transgranicznej. Trzeba bowiem pamiętać, że wraz z intensyfikacją ruchu granicznego bardzo wzrosła też liczba i skala przestępczości granicznej, w tym zwłaszcza przemyt towarów. Na granicy wschodniej i północno-wschodniej powszechnym procederem był drobny przemyt towarów akcyzowych, z których utrzymywali się mieszkańcy rejonów przygranicznych. Równocześnie rozwijała się też poważna przestępczość międzynarodowa, zajmująca się przemytem na olbrzymią skalę (w tym imigrantów), dla której Polska była przede wszystkim krajem tranzytowym.

Po przemianach ustrojowych i geopolitycznych w całej Europie Środkowej i Wschodniej „nowe” polskie granice stały się bez wątpienia granicami tętniącymi ruchem granicznym oraz stopniowo wzrastającą w swojej skali i intensywności lokalną i regionalną współpracą transgraniczną ${ }^{11}$. Skutkowało to stopniowym przełamywaniem zacofania i peryferyjności terenów przygranicznych, które zyskały nowe możliwości rozwoju gospodarczego, społecznego, a także kulturalnego. Granice polskie w okresie lat 90 . XX w. charakteryzowały się stosunkowo wysokim stopniem ich otwartości, zwłaszcza w zakresie obowiązywania minimalnych wymogów formalno-prawnych przekraczania granic. Główne ograniczenia obecne wówczas w ruchu graniczny wynikały z niewystarczającej liczby przejść granicznych i deficytów w zakresie praktyk kontrolnych, które powodowały piętrzenie się kolejek w przejściach granicznych. Należy też podkreślić, że po 1989 r. Polska powróciła do roli kraju tranzytowego w odniesieniu do szlaków komunikacyjnych zarówno istotnych w handlu międzynarodowym, jak i przemieszczaniu się ludności. Poza wynikającymi z tego pozytywnymi, prorozwojowymi tendencjami, skutkowało to też ujawnieniem stosunkowo wysokiego stopnia przepuszczalności polskich granic i pojawieniem się na nich przestępczości transgranicznej, która stanowiła nowe wyzwanie dla służb granicznych.

11 Współpraca transgraniczna rozwijała się dynamicznie zwłaszcza na granicy z Niemcami, gdzie powstały Euroregiony, dysponujące możliwościami finansowania projektów na rzecz tej współpracy z funduszy UE. W ramach tych działań realizowano wspólne inicjatywy infrastrukturalne, nie tylko z zakresu infrastruktury podstawowej (dróg, mostów, przejść granicznych, oczyszczalni ścieków), a także poprzez budowę wspólnych szkół, a nawet uniwersytetu (Uniwersytet Europejski Viadrina we Frankfurcie nad Odrą). 


\section{GRANICA POLSKI A AKCESJA DO UE I STREFY SCHENGEN}

Gruntowne zmiany statusu polskich granic i pełnionych przez nie funkcji kontrolnych następowały w ramach procesu akcesyjnego Polski do UE, dostosowującego polskie prawodawstwo do standardów i rozwiązań unijnych, także w zakresie ochrony granic i kontroli ich przekraczania ${ }^{12}$. Przystąpienie do UE oznaczało bowiem konieczność przyjęcia przez Polskę wszystkich rozwiązań instytucjonalno-prawnych oraz zasad i procedur kontroli granicznej uregulowanych w prawie Schengen. Z jednej strony obywatele polscy uzyskali możliwość w pełni swobodnego podróżowania po całym obszarze Schengen, z drugiej obligowało to Polskę do uszczelnienia jej wschodniej granicy.

Akcesja Polski do strefy Schengen nie nastąpiła automatycznie z dniem 1 maja 2004 r., ale na podstawie decyzji Rady, potwierdzającej wdrożenie przepisów Schengen oraz skuteczne wypełnianie wszystkich zobowiązań wynikających z tych przepisów przez polskie służby. Zgodnie z tymi procedurami włączenie się Polski do strefy Schengen (wraz z 8 innymi nowymi państwami członkowskimi UE) nastąpiło z dniem 21 grudnia 2007 r., gdy zniesiono kontrole na lądowych i morskich granicach Polski z innymi krajami strefy Schengen. Od 30 marca 2008 r. swobodą przekraczania tych wspólnych granic objęto także granice powietrzne.

Jednak aby to było możliwe, już na kilka lat przed formalną akcesją Polski do UE rozpoczął się proces przekształceń, polegający na stopniowym dywersyfikowaniu funkcji i znaczeń poszczególnych odcinków polskich granic. Dotychczasowe granice z Czechami, Litwą, RFN i Słowacją ${ }^{13}$ miały bowiem wkrótce stać się granicami wewnętrznymi UE (i strefy Schengen), zaś granice z Białorusią, Federacją Rosyjską i Ukrainą miały być granicami zewnętrznymi UE (i strefy Schengen). Podział na granice wewnętrzne i zewnętrzne UE wiązał się z pełnieniem całkowicie odmiennych funkcji przez te granice w strefie Schengen i oznaczał konieczność przygotowania części polskich granic do całkowitego

12 Za początek tego procesu przyjąć można datę 20 marca 1997 r., kiedy to rząd RP złożył w Brukseli memorandum wyrażające wolę dostosowania poziomu bezpieczeństwa na granicach zewnętrznych do obowiązujących w UE.

13 Początkowo przygotowania do przejęcia statusu i funkcji wewnętrznych granic UE i strefy Schengen przez część polskiej granicy nie dotyczyły granicy ze Słowacją i Litwą, które nie znalazły się w grupie krajów, którym UE w grudniu 1997 r. wyznaczyła termin rozpoczęcia negocjacji akcesyjnych. Sytuacja ta zmieniła się dopiero po 1999 r., gdy Unia na szczycie w Helsinkach zgodziła się rozpocząć negocjacje także ze Słowacją, Litwą oraz Łotwą, Bułgarią, Rumunią i Maltą. 
zniesienia prowadzonych na nich standardowych kontroli granicznych, zaś na pozostałych odcinkach wprowadzenia wzmocnionych działań kontrolnych w przejściach granicznych oraz skutecznej ochrony granicy między przejściami. Ogólnie rzecz biorąc, na granicach z RFN, Czechami, Słowacją i Litwą koncentrowano się na wprowadzaniu uproszczeń w ruchu granicznym (jednak przy formalnym zachowaniu kontroli i ochrony tych granic aż do grudnia 2007 r.), zaś na granicach z Białorusią, Rosją i Ukrainą podwyższano stopień ich szczelności i nieprzepuszczalności tak, aby skutecznie pełniły wszystkie funkcje kontrolne jako granice zewnętrzne UE.

W ramach tych procesów stopniowo europeizowano polskie prawodawstwo w zakresie kontroli granicznej i warunków wjazdu cudzoziemców na terytorium RP (Trojanowska-Strzęboszewska, 2014). Najistotniejsze w tym zakresie były zmiany przepisów o ochronie granicy państwowej ${ }^{14}$, straży granicznej, a także ustawy o cudzoziemcach ${ }^{15}$ i konieczność dostosowania polskiej polityki wizowej do standardów UE ${ }^{16}$.

W zakresie przepisów dotyczących ochrony granicy państwowej i Straży Granicznej przyjęto podstawowe regulacje schengeńskie, takie jak podział na zadania realizowane w przejściach granicznych oraz na ochronę granicy poza przejściami granicznymi, a także podział na kontrolę graniczną, odprawę graniczną, ochronę granicy oraz kontrolę drugiej linii.

Wdrożono system kontroli granicznej, wypracowany w ramach strefy Schengen, odbiegający od zasad i praktyk kontrolnych, stosowanych dotąd na

14 Gruntowana nowelizacja ustawy o ochronie granicy państwowej miała miejsce w czerwcu 2007 r. i była związana z koniecznością uporządkowania zasad przekraczania granicy oraz kontroli granicznej i dostosowania ich do przyjęcia Kodeksu granicznego Schengen.

15 Kluczowe zmiany polegające na transpozycji wspólnotowych zasad regulujących przepływ osób przez granice wprowadzono na mocy Ustawy z dnia 13 czerwca 2003 r. o cudzoziemcach. Ustawa ta określiła zasady i warunki wjazdu na terytorium RP, przejazdu przez to terytorium, pobytu na nim i wyjazdu cudzoziemców z tego terytorium, tryb postępowania oraz organy właściwe w tych sprawach, zgodnie z acquis Schengen. W latach 2003-2013 ustawa ta była wielokrotnie nowelizowana, z uwagi na stale rozwijające się prawodawstwo unijne w tym zakresie. W dniu 12 grudnia 2013 r. przyjęto całkowicie nową ustawę o cudzoziemcach, która weszła w życie 1 maja 2014 r. (Ustawa z dnia 12 grudnia 2013 r., 2013).

16 Kluczowe były w tym zakresie wprowadzenie 1 października 2003 r. obowiązku wizowego dla obywateli Federacji Rosyjskiej, Republiki Białorusi i Ukrainy oraz likwidacja uproszczonego ruchu granicznego z tymi krajami. W środowiskach eksperckich wyrażano obawy, że zmiana ta wpłynie nie tylko negatywnie na funkcjonowanie społeczności przygranicznych, żyjących z handlu przygranicznego, ale także w perspektywie długofalowej odbije się negatywnie na stosunkach między Polską a jej wschodnimi sąsiadami (Gromadzki, 2001). 
polskich granicach. System ten różnicował kontrole graniczne na stałe i wyrywkowe, szczegółowe i uproszczone, dedykowane konkretnym typom granic (zewnętrznym lub wewnętrznym) oraz stosowane wobec określonych kategorii cudzoziemców ${ }^{17}$.

Zmianom tym towarzyszył proces przekształceń Straży Granicznej, który rozpoczął się w 2000 r. i przebiegał dwutorowo: obejmując z jednej strony alokację sił wynikającą ze zmiany statusu poszczególnych odcinków polskich granic, $\mathrm{z}$ drugiej zaś modyfikację wewnętrznej struktury organizacyjnej i zarządzania formacją. Alokacja zasobów kadrowych SG oznaczała zmniejszanie stanu liczebnego funkcjonariuszy na granicach wewnętrznych i ich zwiększenie na granicach zewnętrznych UE ${ }^{18}$. Przy czym „na wschodzie i północy kraju skoncentrowane zostały siły i środki służące fizycznej ochronie granicy i kontroli ruchu granicznego, podczas gdy na południu i zachodzie skupiono się na pracy operacyjnej i dochodzeniowej oraz na lotnych wyrywkowych kontrolach dokonywanych w głębi kraju" (Pietraszczyk, 2008, s. 65). Innym elementem tego procesu było uzawodowienie Straży Granicznej, wzmocnienie potencjału kadrowego tej formacji oraz przeprowadzanie szkoleń przygotowujących strażników do wykonywania nowych zadań (m.in. wykrywania nielegalnej imigracji czy zwalczania terroryzmu) i sprostania standardom kontroli stosowanym w strefie Schengen (zwłaszcza niedopuszczanie do korupcji wśród strażników). Efektem końcowym tych przekształceń była całkowita transformacja SG (do 2015 r.) w nowoczesną służbę graniczno-imigracyjną o charakterze policyjnym, przy uwzględnieniu takiego podziału sił i środków, który odpowiadałby podziałowi na granice wewnętrzne i zewnętrzne UE.

Równocześnie przeprowadzano szereg zmian w zakresie infrastruktury granicznej, dostosowujących polską granicę do funkcji pełnionych w systemie Schengen. Na granicach lądowych z Czechami, Litwą, Niemcami i Słowacją

17 Zgodnie z Kodeksem granicznym Schengen obywatele krajów trzecich muszą przechodzić przy wjeździe „szczegółową i ujednoliconą odprawę”, bez względu na to, czy obowiązuje ich posiadanie wizy czy nie. Odprawa ta każdorazowo obejmuje kontrolę dokumentu podróży, ustalenie celu i długości pobytu oraz sprawdzenie, czy dana osoba posiada dostateczne środki utrzymania, sprawdzenia tej osoby w SIS i krajowych bazach danych pod kątem stwarzania zagrożeń. Jedynym odstępstwem w tym zakresie są procedury uproszczonej odprawy stosowane wobec osób korzystających z małego ruchu granicznego. Z kolei obywatele UE zarówno przy wjeździe, jak i wyjeździe przechodzą „odprawę minimalną”, polegającą na zbadaniu dokumentów podróży w celu weryfikacji tożsamości. (Rozporządzenie Parlamentu Europejskiego i Rady (WE) nr 562/2006 z dnia 15 marca 2006 r.).

18 W 2009 r. przyjęto, że docelowo infrastruktura SG obejmować będzie 95 placówek SG, w tym 79 ulokowanych na granicy zewnętrznej (Straż Graniczna, 2009). 
zmiany polegały na likwidacji wszystkich przeszkód utrudniających swobodny przejazd przez granicę. W tym celu likwidowano infrastrukturę graniczną lub zmieniano jej przeznaczenie (np. na cele szkoleniowe). W okresie od stycznia 2004 r. do 31 grudnia 2008 r. z systemu ochrony odcinków granicy państwowej, będących granicą wewnętrzną UE, wyłączono 56 placówek SG. W tym samym czasie stopniowo rozbudowywano i modernizowano dotychczasową infrastrukturę graniczną na granicy z Białorusią, Rosją i Ukrainą. W 2005 r. funkcjonowało 12 przejść granicznych (drogowych i kolejowych) na granicy z Ukrainą, 6 z Rosją (i jedno dodatkowe przeznaczone wyłącznie dla uproszczonego ruchu granicznego) i 13 z Białorusią (w tym jedno rzeczne) (Moraczewska, 2008) Do 2015 r. otworzono jeszcze to dwa nowe przejścia drogowe z Ukrainą. Ponadto zmianami objęto też infrastrukturę graniczną w portach lotniczych, gdzie wprowadzono rozróżnienie na ruch pasażerski prowadzony w strefie Schengen i poza nią. Ale przede wszystkim z uwagi na dużą skalę ruchu granicznego na całej polskiej granicy zewnętrznej UE skoncentrowano się na działaniach zwiększających płynność ruchu granicznego przy równoczesnym wzmocnieniu skuteczności działań kontrolnych zarówno w przejściach granicznych, jak i między nimi.

Pomimo wielu zmian wprowadzonych już w latach 90., konieczna była też dalsza modernizacja sprzętu, a zwłaszcza zakup nowoczesnych urządzeń, niezbędnych do wykonywania całkiem nowych zadań Straży Granicznej (takich jak działania związane z nielegalnym pobytem i zatrudnianiem cudzoziemców, wykonywanie analiz kryminalistycznych i analiz ryzyka, walka z terroryzmem). Do końca 2007 r. szczególnym wyzwaniem było też dostosowanie polskich służb granicznych do najnowocześniejszych rozwiązań teleinformatycznych, w tym podłączenie wszystkich placówek granicznych do bazy Systemu Informacyjnego Schengen II. Straż Graniczna, by skutecznie wykonywać swoje zadania kontrolne, musiała bowiem zyskać szybki dostęp do zbioru danych osób i towarów (m.in. skradzionych, poszukiwanych, niepożądanych w UE) oraz zapewnić najwyższy poziom ochrony tych poufnych informacji. Zmiany te wymiernie skróciły czas oczekiwania i przeprowadzania odpraw granicznych na granicach wschodnich, a także wyraźnie usprawniły pracę funkcjonariuszy w walce z przestępczością transgraniczną.

Pierwotne obawy, że przystąpienie Polski do UE i strefy Schengen, a wraz z tym przyjęcie unijnego prawodawstwa w zakresie polityki wizowej, zasad przekraczania granic i ich kontroli negatywnie odbiją się na dynamice ruchu granicznego na nowych granicach zewnętrznych UE, nie potwierdziły się. 
Znaczący, ale krótkotrwały spadek ruchu granicznego odnotowano jedynie po wprowadzeniu obowiązku wizowego dla obywateli Ukrainy, Białorusi i Rosji w 2003 r., co wynikało z dostosowań polskiego prawa wizowego do rozwiązań unijnych. Największy spadek odnotowano wówczas na granicy z Ukrainą, ale już od 2004 r. ponownie odnotowano wzrost ruchu na tej granicy. Dane dotyczące ruchu granicznego pokazują, że łącznie w 2004 r. na granicy wschodniej przeprowadzono $33 \mathrm{mln}$ odpraw w osobowym ruchu granicznym, co stanowiło spadek tylko o 1,4\% w porównaniu do roku ubiegłego (cyt. za Trojanowska-Strzęboszewska, 2005, s. 32). W kolejnych latach natężenie ruchu granicznego utrzymywało się na podobnym poziomie, $\mathrm{z}$ wahaniami raz $\mathrm{w}$ jedną bądź drugą stronę, w zależności od zmieniających się szczegółowych przepisów regulujących zasady przekraczania granic przez osoby i towary.

Władze polskie, aby ograniczyć ewentualne negatywne konsekwencje uszczelnienia granicy wschodniej w związku przejęciem przez nią roli granicy zewnętrznej strefy Schengen, skorzystały z pewnej elastyczności przepisów schengeńskich i wprowadziły liberalizację przepisów dotyczących przekraczania tej granicy przez wybrane kategorie osób. Kluczowe w tym aspekcie było podpisanie z krajami sąsiednimi umów o małym ruchu granicznym, odnoszących się do mieszkańców terenów przygranicznych (strefy sięgającej do $30 \mathrm{~km}$ od granicy, a w szczególnych przypadkach nawet do 50 km). W 2009 r. taka umowa weszła w życie z Ukrainą, a w 2012 r. z Rosją. Na mocy tych umów obywatele obu państw zamieszkujący w strefie przygranicznej uzyskali możliwość wielokrotnego przekraczania granicy z powodów społecznych, kulturalnych, rodzinnych, ekonomicznych (z wyłączeniem zarobkowych) na uproszczonych zasadach, tj.np. bez konieczności posiadania paszportu, wizy, określonej sumy środków pieniężnych. W odniesieniu do umowy z Ukrainą, że przepisy te mają większe znaczenie dla obywateli tego kraju niż Polski, gdyż Polacy mogli też wcześniej podróżować i przebywać na terytorium Ukrainy do 90 dni bez konieczności posiadania wiz. Należy podkreślić, że zarówno mały ruch graniczny z Ukrainą, jak i z Rosją jest „korzystniejszy od uproszczonego ruchu granicznego, realizowanego na granicy wschodniej przed przystąpieniem Polski do UE” (Parol, 2014, s. 203).

Innym ułatwieniem w przekraczaniu polskiej granicy było wejście w życie w 2008 r. ustawy o Karcie Polaka. Zapewniła ona obywatelom państw byłego ZSRR, posiadającym polskie pochodzenie i przyznającym się do polskości, m.in. bezpłatne otrzymanie długoterminowej wizy pobytowej, umożliwiającej wielokrotne przekraczanie granicy z Polską (poza innymi prawami jak prawo pobytu i zatrudnienia oraz nauki na terytorium polskim). W ciągu trzech i pół 
roku obowiązywania tej ustawy o przyznanie Karty Polaka wystąpiło ponad 75 tys. osób, z czego ponad 88\% stanowili obywatele Ukrainy i Białorusi (Wołłejko, 2011).

Dotychczasowe badania pokazują, że wprowadzenie ułatwień w przekraczaniu granicy, zwłaszcza dzięki małemu ruchowi granicznemu, wywarło korzystny wpływ na zwiększenie ruchu granicznego, ale też wielkość wydatków ponoszonych przez cudzoziemców w polskiej strefie przygranicznej (Główny Urząd Statystyczny, 2015). Miało to, i nadal ma, ważne pozytywne konsekwencje dla ekonomicznego wymiaru funkcjonowania polskich regionów przygranicznych, zwłaszcza wobec społecznych obaw, że uszczelnienie wschodnich granic jako granic strefy Schengen negatywnie odbije się na życiu społeczności przygranicznych.

Niemniej wprowadzone rozwiązania ułatwiające przekraczanie granic wschodnich będących teraz granicami zewnętrznymi UE nie zniwelowały olbrzymiej dysproporcji w funkcjonowaniu poszczególnych odcinków polskich granic, który stał się faktem od 2009 r. Zasadniczy podział polskich granic na wewnętrzne i zewnętrzne granice UE i strefy Schengen różnicuje te granice pod wieloma względami. Po pierwsze, odzwierciedla się on w skali ruchu granicznego na tych dwóch typach granic. W 2014 r. natężenie ruchu granicznego na polskich granicach wewnętrznych UE było 6-krotnie wyższe niż na granicach zewnętrznych (tamże, s. 73). Wynika to przede wszystkim z braku jakichkolwiek ograniczeń w swobodzie przepływu osób na granicach wewnętrznych, przy równoczesnym wprowadzeniu szeregu obostrzeń dotyczących warunków przekraczania granic zewnętrznych UE i możliwości uzyskania wizy schengeńskiej oraz prawa pobytu w strefie Schengen przez obywateli państw trzecich. Po drugie, odmienne są zasady patrolowania i kontroli na tych odcinkach granic. Na granicy zewnętrznej UE są prowadzone systematyczne i szczegółowe kontrole graniczne, wzmocnione dodatkowo środkami kontrolnymi w ramach procedur wizowych czy azylowych prowadzonych na terytoriach krajów trzecich. Zaś na granicach wewnętrznych zabronione jest prowadzenie działań mających znamiona kontroli granicznych i zastępuje się je działaniami policyjnymi, prowadzonymi na równych zasadach na całym terytorium strefy Schengen. Po trzecie, o ile na granicach wewnętrznych wyraźnie zaciera się namacalny, infrastrukturalny wymiar funkcjonowania granicy, na co wpływ mają też liczne przedsięwzięcia transgraniczne (jak wspólne szlaki komunikacyjne czy obiekty infrastruktury podstawowej), o tyle na granicach zewnętrznych UE zyskuje on na sile, a same granice stają się wyraźne w prze- 
strzeni fizycznej oraz odgrywają istotną rolę w działaniach i wyobrażeniach mieszkańców terenów przygranicznych.

Reasumując, wraz członkostwem Polski w UE i strefie Schengen intensywnej transformacji poddano zwłaszcza organizację i zarządzanie polskimi granicami, które dostosowano do standardów i rozwiązań instytucjonalno-prawnych unijnego zintegrowanego systemu zarządzania granicami zewnętrznymi UE. Tym gruntownym zmianom funkcjonalnym polskich granic towarzyszyła też fundamentalna zmiana ich statusu. Obecnie są to bowiem nie tylko granice międzypaństwowe, ale także granice (wewnętrzne lub zewnętrzne) szczególnej wspólnoty politycznej. Powoduje to, że w odniesieniu do odcinków polskiej granicy, które stały się wewnętrznymi granicami UE i na których wprowadzono pełną swobodę przepływu osób, pojęcie granica państwowa traci aspekt praktyczny, zachowując jednak wymiar symboliczno-polityczny. Z kolei na odcinkach granic wschodnich i południowych, które przejęły funkcję granicy zewnętrznej UE, „pojęcie granicy państwowej wzmacnia się w wymiarze praktycznym, zaś $\mathrm{w}$ wymiarze symboliczno-politycznym poddawane jest redefinicji w kierunku granicy o charakterze wspólnotowym, tj. odnoszącej się do sui generis terytorialnie zorganizowanej wspólnoty politycznej" (Trojanowska-Strzęboszewska, 2014, s. 324). Polskie granice, które zyskały status zewnętrznej granicy UE, przestają pełnić funkcje istotne jedynie z punktu widzenia ochrony i bezpieczeństwa polskiego państwa i społeczeństwa, ale stają się także granicami strefy Schengen, biorąc na siebie współodpowiedzialność za kontrolę i ochronę bezpieczeństwa wewnętrznego wszystkich państw członkowskich. To też oznacza zaakceptowanie przez Polskę faktu, że rozstrzygnięcia formalno-prawne określające zasady i procedury kontroli oraz ochrony polskiej granicy powstają przy udziale wszystkich członków strefy Schengen. Innymi słowy, członkostwo Polski w UE obok licznych korzyści ekonomicznych i społecznych wynikających z funkcjonowania strefy Schengen, przyniosło też pewne ograniczenia dla swobodnego kształtowania polityki państwowej w zakresie zarządzania granicami, kontroli przepływu osób i ochrony granic przed przestępczością transgraniczną.

\section{PODSUMOWANIE}

Ponieważ granice stanowią integralną część państwa, zmiany granic są swoistym miernikiem natury danej państwowości, zakresu jego suwerenności i władzy. Stąd też zmieniające się status polityczny i funkcje kontrolne polskich granic 
stanowią też soczewkę, w której skupiają się fundamentalne zmiany polskiej państwowości. Powyższe analizy widocznie potwierdziły tezę, że „granice są znakami suwerenności i stanu posiadania państwa oraz znakami pokojowych lub wrogich relacji między państwem a jego sąsiadami” (Donnan, Wilson, 2007, s. 32). Przeobrażenia, jakim poddano polskie granice od okresu powojennego do lat dzisiejszych, uwypuklają fundamentalne zmiany, jakie przeszło polskie państwo w zakresie suwerenności w polityce wewnętrznej i zewnętrznej oraz jego roli i znaczenia w polityce międzynarodowej.

Ograniczona suwerenność polskiego państwa w okresie PRL przełożyła się na poddanie polskich granic zasadom funkcjonowania narzuconym przez ZSRR całemu blokowi wschodniemu. Cechowało je hermetyczne wręcz izolowanie obywateli własnego państwa od wpływów zewnętrznych, nie tylko ze świata zachodniego, ale także z pozostałych państw komunistycznych. Wraz z przemianami politycznym, demokratyzacją i odzyskaniem pełnej suwerenności zmieniły się też zasady funkcjonowania granic III Rzeczpospolitej. Z jednej strony nie były one już barierą w mobilności dla polskich obywateli, ale z drugiej stopniowo stawały się instytucjami kontroli przed zagrożeniami dla bezpieczeństwa wewnętrznego płynącymi z zewnątrz. Trzecia, pełzająca transformacja, związana z europeizacją polskich granic rozumianą jako przyjmowanie unijnego dorobku prawnego oraz standardów i praktyk kontrolnych, zdywersyfikowała polskie granice na granice wewnętrzne i zewnętrzne UE, zgodnie z tym, że Polska, będąc państwem członkowskim, przyjęła też zadania kraju granicznego Unii. Polscy, obywatele stając się równocześnie obywatelami UE, uzyskali prawo do swobodnego podróżowania po całym obszarze strefy Schengen, a przekraczając zewnętrze granice UE, objęci zostali uproszczonymi procedurami kontroli. Z kolei wobec obywateli państw trzecich rozumianych odtąd jako obywatele państw niebędących członkami UE i strefy Schengen wprowadzono wzmocnione i systematyczne kontrole tak przy wjeździe do, jak i wyjeździe z UE. Przy czym zasadniczym instrumentem realizacji owych funkcji kontrolnych i ochrony bezpieczeństwa wewnętrznego całej UE stały się także polskie odcinki granic zewnętrznych UE. W tym sensie fakt członkostwa Polski w UE, wywierając olbrzymi wpływ na status polityczny i funkcje kontrolne polskich granic, stanowi część fundamentalnej wręcz zmiany natury polskiej państwowości polegającej na byciu państwem członkowskim UE. Oznacza to, że to właśnie od natury politycznej tej wspólnoty, zakresu jej uprawnień oraz typu terytorialności, na jakim się ona opiera, zależą także status i funkcje, jakie zarówno obecnie, jak i w przyszłości pełnić będą polskie granice. 
Bibliografia:

Sytuacja na granicy z Rosją, Litwą, Białorusią i Ukrainą. Informacja Komendy Głównej Straży Granicznej, (1998). Przeglad Rządowy, 9, s. 179-201.

Anderson, M. (1996). Frontiers. Territory and State Formation in the Modern World. Cambridge: Polity Press.

Anderson, M., Bort, E. (2001). The Frontiers of the European Union. New York: Palgrave. Andreas, P. (2003). Redrawing the Line: Borders and Security in the Twenty-Firs Century. International Security, s. 28 (2), 78-111.

Andreas, P., Snyder, T. (red.). (2000). The Wall Around the West: State Border and Immigration Controls in North America and Europe. Lanham: Rowman and Littelfield.

Boggs, W.S. (1940). International Boundaries: A Study of Boundary Functions and Problems. New York: Columbia University Press.

Dominiczak, H. (1997). Granice państwa i ich ochrona na przestrzeni dziejów 966-1996. Warszawa: Wydawnictwo Bellona.

Donnan, H., Wilson, T.M. (2007). Granice tożsamości, narodu, państwa. Kraków: Wydawnictwo Uniwersytetu Jagiellońskiego.

Eberhardt, P. (1993). Polska granica wschodnia 1939-1945. Warszawa: Editions Spotkania.

Główny Urząd Statystyczny. (2015). Ruch graniczny oraz wydatki cudzoziemców w Polsce i Polaków za granica w 2014 r. Warszawa-Rzeszów.

Gromadzki, G. (2001). Konsekwencje polityczne umowy z Schengen - problemem dla całej rozszerzonej Unii. W: Polska droga do Schengen. Opinie ekspertów (s. 41-66). Warszawa: Instytut Spraw Publicznych.

Langer, J. (1999). Towards a conceptualization of border: the Central European Experience. W: H. Eskelinen, I. Liikanen, J. Oksa (red.), Curtains of Iron and Gold - Reconstructing Borders and Scales of Interaction (s. 25-42). Aldershot: Ashgate. Pobrane z: http://www.kakanien-revisited.at/beitr/theorie/jlanger3.pdf (22.05.2016).

Moraczewska, A. (2008). Transformacja funkcji granic Polski. Lublin: UMCS.

Murray, P., Holmes, L. (red.). (1998). Europe: Rethinking the Boundaries. Aldershot: Ashgate.

O’Dowd, L. (2001). Analysing European Borders. IBRU Boundary and Security Bulletin, Summer, s. 67-79.

Parol, A. (2014). Konsekwencje członkostwa w Unii Europejskiej i strefie Schengen dla ruchu osobowego na wschodniej granicy Rzeczypospolitej Polskiej - analiza prawna. W: A. Kuś, A. Szachoń-Pszenny (red.), Wpływ acquis communautaire $i$ acquis Schengen na prawo polskie -doświadczenia i perspektywy (s. 187-206). Lublin: Wydawnictwo KUL.

Pietraszczyk, M. (2008). Funkcjonowanie straży granicznej w warunkach strefy Schengen. W: Polska w strefie Schengen. Refleksje po pierwszym roku członkostwa (s. 64-72). Warszawa: MSWiA.

Rościszewski, M. (1997). Polska granica wschodnia. Geopolitical Studies 1. 
Roszkowski, W. (2007). Historia Polski 1914-2005. Warszawa: Wydawnictwo Naukowe PWN.

Rozporządzenie Parlamentu Europejskiego i Rady (WE) nr 562/2006 z dnia 15 marca 2006 r. ustanawiające wspólnotowy kodeks zasad regulujących przepływ osób przez granice (kodeks graniczny Schengen). Dz.Urz. UE L 105 z dn. 13.4.2006.

Sadowski, S. (2001). Polska granica wschodnia w okresie zimnowojennego podziału Europy w latach 1949-1989. W: W. Wróblewski (red.), Wschodnia granica Polski. Przeszłość i teraźniejszość. Materiały z konferencji naukowej, Lublin 24 maja 2001 (s. 149-164). Lublin: Wydawnictwo Comandor.

Sobczyński, M. (2008). Zmienność funkcji granic międzynarodowych na ziemiach polskich od czasów rzeczypospolitej szlacheckiej do przystąpienia Polski do układu z Schengen. W: P. Eberhardt (red.), Problematyka geopolityczna ziem polskich (s. 29-54). Warszawa: IGiPZ PAN. Pobrane z: http://rcin.org.pl/Content/130/ WA51_228_r2008-t218_Prac-Geogr.pdf.

Straż Graniczna. (2009). Założenia wieloletniej koncepcji funkcjonowania Straży Granicznej na lata 2009-2015 (główne aspekty dokumentu). Straż Graniczna Magazyn, 5.

Trojanowska-Strzęboszewska, M. (2005). Krótka charakterystyka granic wschodnich III RP. W: J. Kurczewska, H. Bojar (red.), Granice na pograniczach. Z badań społeczności lokalnych wschodniego pogranicza Polski (s. 29-33) Warszawa: Wydawnictwo IFiS PAN.

Trojanowska-Strzęboszewska, M. (2014). Przystąpienie do UE i strefy Schengen a kontrola graniczna i warunki wjazdu cudzoziemców na terytorium RP. W: A. Kuś, A. Szachoń-Pszenny (red.), Wpływ acquis communautaire $i$ acquis Schengen na prawo polskie - doświadczenia i perspektywy (s. 311-334). Lublin: KUL.

Ustawa z dnia 12 grudnia 2013 r. o cudzoziemcach. Dz.U. 2013 poz. 1650.

Ustawa z dnia 12 października 1990 r. o ochronie granicy państwowej. Dz.U. $1990 \mathrm{nr} 78$, poz. 461.

Wołłejko, M. (2011). Realizacja ustawy o Karcie Polaka w latach 2008-2011 - sukces czy porażka?. Bezpieczeństwo Narodowe, 20, s. 149-158. 